AT-TASYRI' Jurnal Ilmiah Prodi Muamalah

P-ISSN: 2085-2541, E-ISSN: 2715-7865

Volume 13, Nomor 1, Juni 2021

https://ejournal.staindirundeng.ac.id/index.php/Tasyri

\title{
KESAKSIAN WANITA DALAM PERKARA PIDANA (Analisis Pemikiran Muhammad al-Ghazali)
}

\author{
Asy'ari \\ STAIN Teungku Dirundeng Meulaboh \\ asyari@staindirundeng.ac.id
}

\begin{abstract}
Abstrak
Jumhur ulama tidak menerima kesaksian wanita dalam perkara pidana, pendapat mereka didasarkan kepada nash serta jumhur ulama memandang bahwa wanita memiliki sifat pelupa dan ragu-ragu dan lazimnya wanita tidak kuat menyaksikan peristiwa kriminal. Keraguan tidak bisa dijadikan argument karena dikhawatirkan merugikan orang lain. Artikel ini bertujuan untuk menganalisis pemikiran Muhammad al-Ghazali tentang kesaksian wanita dalam perkara pidana. Muhammad al-Ghazali membolehkan kesaksian wanita dalam perkara pidana sesuai dengan batasan saksi di dalam al-Qur'an. Pendapat Muhammad al-Ghazali yang berbeda dengan jumhur ulama didasarkan oleh cara pandang dan metode yang dia gunakan.
\end{abstract}

Kata kunci: Kesaksian Wanita, Perkara Pidana, Muhammad al-Ghazali

\begin{abstract}
Most scholars do not accept the witness of women in criminal cases, their opinions are relied on nash and they consider that women are forgetful and doubt and generally women are not strong enough to witness any criminal events. Doubt cannot be used as an argument because it is feared to harm others. This goal of this article analyzing Muhammad al-Ghazali's concept on witness of woman in criminal cases. Muhammad al-Ghazali, allows the witness of women in criminal cases in accordance with the limitations of witnesses in the Qur'an. This Muhammad al-Ghazali's opinion differs from the scholars based on the perspective and method he used.
\end{abstract}

Keywords: witness of women, criminal cases, Muhammad al-Ghazali

\section{A. PENDahuluan}

Saksi merupakan hal yang sangat penting dalam pembuktian tindak pidana. Setiap perkara yang diajukan ke pengadilan diperlukan alat bukti yang sah, salah satunya yaitu bukti saksi. Hukum Islam sangat teliti dalam memutuskan suatu perkara dengan adanya alat-alat bukti, termasuk adanya bukti saksi. Apalagi perkara yang diajukan ke pengadilan itu merupakan perkara pidana. Seorang hakim harus jeli menerima kesaksian para saksi, sebab kesaksian itu berpengaruh terhadap putusan hakim dan hukuman yang diputuskan. Kalau hakim tidak teliti dan tidak pandai dalam memutuskan suatu perkara, maka sangat dikhawatirkan banyaknya orang yang menjadi korban, baik nyawa atau fisik karena keputusan hakim yang salah.

Dalam hukum Islam para ulama sepakat menerima kesaksian laki-laki dalam semua perkara denga syarat dipenuhinya syaratsyarat menjadi saksi. Kesaksian laki-laki dalam beberapa perkara dibedakan jumlahnya 
sesuai dengan perkara yang diadili. Perkara zina tidak boleh kurang dari empat orang saksi. Dalam kasus yang lainnya ada dengan didatangkan dua orang saksi seperti perkara yang diancamkan hukuman had selain zina. ${ }^{1}$

Namun para ulama berbeda pendapat tentang kesaksian wanita atau kesaksian lakilaki bersama dengan wanita. Jumhur ulama sepakat menerima kesaksian dua orang lakilaki atau seorang laki-laki dengan dua orang perempuan dalam setiap masalah yang menyangkut harta benda. Sedangkan dalam masalah pidana, jumhur ulama sepakat tidak menerima kesaksian wanita dengan alasan dan kondisi apapun. $^{2}$

Melihat fenomena yang terjadi sekarang ini, dimana dunia semakin canggih, perkembangan zaman semakin pesat serta keadaaan kultur dan budaya masyarakat telah berubah. Banyak kejahatan dan perkara pidana yang terjadi terhadap wanita atau perkara pidana itu terjadi di depan mereka seperti di asrama putri atau ditempat-tempat lain yang di situ hanya ada wanita. Bisa saja perkara pidana itu terjadi di depan laki-laki dan wanita tetapi jumlah saksi laki-laki kurang dari batas yang telah ditentukan oleh jumhur ulama.

Apakah kejahatan itu dibiarkan tanpa ada putusan dan hukuman dengan alasan tidak mencukupi alat bukti? Apakah pelaku dibiarkan berkeliaran tanpa terjerat hukuman? Mengapa tidak diterima kesaksian wanita padahal kejahatan itu terjadi terhadap mereka atau di depan mata mereka?

Melihat permasalahan ini maka Muhammad al-Ghazali mencoba membuka cakrawala berpikir umat Islam dan mereka berusaha mendobrak kebekuan pemikiran yang terjadi. Dalam bukunya as-Sunnah an-
Nabawiyah Baina Ahl al_Fiqh Wa Ahl alHadits terlihat dengan sangat jelas keintelektualan Muhammad al-Ghazali, dia tidak hanya terpaku dengan persyaratan yang dibuat oleh ulama hadits dalam menilai suatu hadits tetapi ada yang lebih penting bagi dirinya yaitu kepentingan kaum muslimin. Namun demikian tidak berarti dia tidak mengakui ulama-ulama sebelumnya. Oleh karena itu sangat penting mengetahui konsep dan metode yang digunakan Muhammad alGhazali dalam mengemukakan pendapatnya tentang kesaksian wanita dalam perkara pidana.

\section{B. Biografi Muhammad al-Ghazali}

Muhammad al-Ghazali as-Saqa lahir pada tanggal 22 September $1917 \mathrm{M}$ di kampung Naklal Inab, itay al-Barud, alBahirah- Mesir. Dia dibesarkan dalam keluarga agamis yang sibuk dengan perdagangan. Ayahnya seorang hafidz alQur'an. Muhammad al-Ghazali hafal alQur'an semenjak berusia sepuluh tahun.

Pendidikannya dimulai dari otodidak dan menerima ilmu dari guru-guru di kampungnya, sampai masuk al-Azhar dan memperoleh sertifikat pengajaran pada tahun 1941. Dia masuk sekolah agama di Iskadariah dan menamatkan tingkat dasar hingga menengah atas (SMU). Kemudian tahun 1937 pindah ke Kairo untuk melanjutkan kuliah di Fakultas Ushuluddin dan dia mendapat gelar ijazah master dari Fakultas Bahasa Arab pada tahun 1943. Muhammad al-Ghazali mengambil spesialisasi di dakwah wal irsyad

\footnotetext{
${ }^{1}$ Muhammad Salam Madkur, Peradilan Dalam Islam (terj. Imron AM), Surabaya: PT. Bina Ilmu, 1993, h. 105

2 Ibnu Rusyd, Bidayatul Mujtahid (terj. Imam Ghazali Said), Jilid 3, Semarang: CV. Asy-Syifa, 1990, h. 691
} 
dan mendapatkan gelar magister pada tahun 1943 M. $^{3}$

Selain berkecimpung dalam dakwah, Muhammad al-Ghazali juga bergelut di dunia pendidikan dan kebudayaan. Dia pernah menjabat beberapa posisi penting diantaranya dosen Universitas al-Azhar pada Fakultas Syari'ah, Ushuluddin, Dirasah al-Arabiyah Wa Islamiyah dan Fakultas Tarbiyah. ${ }^{4}$

Menjabat sebagai Dewan penasihat masjid pada tahun 1941. Pada tanggal 20 November 1961 dilantik sebagai sekretariat lembaga tinggi urusan Islam, pengawas umum bidang dakwah pada kementerian wakaf merangkap sebagai direktur umum lembaga masjid pada tahun 1964. Pada tanggal 1 Juli 1971 dilantik sebagai pimpinan umum dakwah islamiyah pada kementerian wakaf, beliau juga pernah menjadi dosen tamu di Universitas Ummul Qura tahun 1971. Dosen pascasarjana dan Ketua Jurusan Dakwah Fakultas Syari'ah Universitas King Abdul Aziz tahun 1976. Pada tanggal 7 Maret 1980 dipercayakan sebagai wakil kementerian wakaf bidang dakwah islamiyah dan ketua lembaga ilmiah di Universitas Abdul Qadir alJazairi al-Islamiyah di al-Jazair selama lima tahun. $^{5}$

Dalam usia senjanya Muahmmad alGhazali juga ikut andil dalam gerakan Islamisasi ilmu. Dia juga diangkat menjadi anggota dewan penasehat pada IIIT (International Institute of Islamic Thought) yang bermarkas di Washington. Gagasan Islamisasi ilmu merupakan juga agenda awal pemikiran Muhammad al-Ghazali.

Muhammad al-Ghazali pernah mendapatkan beberapa anugerah dan bintang kehormatan yaitu pada tahun 1988 pemerintah Mesir menganugerahkan bintang kehormatan tertinggi kepadanya. Pemerintah al-Jazair menganugerahkan medali al-Atsir yang merupakan bintang kehormatan tertinggi di alJazair kepadanya dalam bidang dakwah Islam. Dia merupakan orang Mesir pertama yang mendapatkan penghargaan internasional Raja Faisal dari Kerajaan Saudi Arabia dalam bidang pengabdian kepada Islam.

Muhammad al-Ghazali pernah dipenjara dua kali yaitu pada tahun 1949 dia mendekam selama satu tahun di penjara atThur dan tahun 1965 ditahan di penjara Tharah selama beberapa waktu karena keterlibatan beliau dengan gerakan Ikhwanul Muslimin. ${ }^{6}$

Muhammad al-Ghazali merupakan seorang penulis dan Dai yang disegani di dunia Islam, khususnya di kawasan Timur Tengah. Tempat-tempat dia ceramah selalu dipadati oleh ribuan pendengar yang berasal dari berbagai kalangan ulama, cendekiawan, pelajar dan segenap lapisan masyarakat. Dia tidak hanya berdakwah di Timur Tengah namun juga di negara-negara Eropa, dia sering diundang menyampaikan seminar-seminar pemuda dan mahasiswa.

Muhammad al-Ghazali mewariskan enam puluh buku lebih dalam berbagai tema, buku-buku Muhammad al-Ghazali yang terbit lebih dari sekali, yang telah diterjemahkan ke dalam berbagai bahasa seperti Bahasa Inggris, Turki, Perancis, Urdu, Indonesia dan lain sebagainya.

Sebagian bukunya menimbulkan pro dan kontra. Karya puncaknya yang banyak diperbincangkan orang adalah as-sunnah an-

${ }^{3}$ Abdullah al-Aqil, Mereka Yang Telah Pergi (terj. Khozim Abu Faqih), Jakarta: al-I'tishom Cahaya Umat, 2003, h. 16-17.

${ }^{4}$ Muhammad al-Ghazali, Berdialog Dengan Al-Qur'an (terj. Masykur Hakim), Bandung: Mizan, 1999, h. 6

${ }^{5}$ Abdullah al-Aqil, Mereka Yang Telah Pergi,..., h. 17

${ }^{6}$ Abdullah al-Aqil, Mereka Yang Telah Pergi,..., h. 17 
Nabawiyah Baina Ahl al-Fiqh Wa Ahl alHadits. Dalam buku tersebut terlihat dengan sangat jelas sikap intelektual Muhammad alGhazali. Dia tidak terpaku dengan persyaratan yang dibuat oleh ulama hadits dalam menilai sebuah hadits Nabi. Baginya ada yang lebih penting dari sekedar metode yaitu kepentingan kaum muslimin. ${ }^{7}$

Muhammad al-Ghazali meninggal dunia pada hari sabtu tanggal 9 Syawal 1416 $\mathrm{H}$ atau tanggal 6 Maret $1996 \mathrm{M}$ di Riyadh, dia wafat pada usia 78 tahun. ${ }^{8}$

\section{Metode dan Sumber Utama Pemikiran Fiqh Muhammad al-Ghazali}

Adapun metode dan sumber utama pemikiran fiqh yang digunakan Muhammad al-Ghazali adalah:

\section{Al-Quranul Karim}

Al-Qur'an merupakan sumber dan prinsip pertama dalam setiap pengistinbathan suatu hukum karena al-Qur'an merupakan firman Allah yang keshahihan dan kemutawatirannya tidak bisa diragukan lagi sepanjang masa. Allah SWT sendiri yang menjamin al-Qur'an sampai akhir zaman.

Sumber pertama dan utama pemikiran Muhammad al-Ghazali adalah al-Quranul Karim. Dalam setiap buku yang ditulisnya dan dalam berbagai ceramah, seminar dan acara lainnya akan terlihat betapa teguhnya Muhammad al-Ghazali berpegang pada alQur'an dan dia berusaha membandingkan setiap hadits dengan al-Qur'an agar tidak adanya kesalahan apalagi pertentangan antara keduanya. Maka seharusnya penjelas tidak boleh bertentangan dengan apa yang dijelaskan.

Barangsiapa yang pernah mendengar ceramah dan membaca karangannya sejak beliau masih muda, maka ia akan yakin benar betapa dalamnya pemahaman beliau terhadap al-Qur'an. Betapa mahirnya beliau dalam mengungkap dan menjelaskan makna-makna dan rahasia-rahasianya. ${ }^{9}$

Menurut Muhammad al-Ghazali dalam memahami al-Qur'an diperlukan metode baru yang sejalan dengan metode al-Qur'anyang universal. Hal ini bisa terwujud bila setiap disiplin ilmu yang sudah ada sekaligus metodenya, dikaji dan diteliti sesuai dengan al-Qur'an. Hal ini dikarenakan al-Qur'an tidak dikotomis dan parsial tetapi universal. Meski demikian dituntut untuk berusaha membuat interpretasi rasional atau berusaha keras untuk mengungkap rahasia-rahasia dibalik pernyataan ayat-ayat dan menyimpulkannya untuk menjadi satu dasar yang utuh dengan cara mencontoh metodologi al -Qur'an yang universal. ${ }^{10}$

Oleh sebab itulah Muhammad alGhazali membantah bila dikatakan bahwa sunnah bertentangan dengan al-Qur'an. Demikian juga penakwilannya tidak boleh dibuat-buat. Muhammad al-Ghazali mengatakan bahwa bila hadits yang diriwayatkan dari seorang yang tsiqah bertentangan dengan hadits lain yang diriwayatkan oleh orang yang lebih tsiqah, maka hadits tersebut dianggap syadz atau hadits itu berubah dari status maqbul kepada mardud atau dari statusnya sebagai hadits hasan kepada hadits dhaif. Jika demikian

\footnotetext{
${ }^{7}$ Abdullah al-Aqil, Mereka Yang Telah Pergi,..., h. 21-23

${ }^{8}$ Muhammad al-Ghazali, Berdialog Dengan Al-Qur'an,...h. 9

${ }^{9}$ Yusuf Al-Qardhawi, Syaikh Muhammad Al-Ghazali Yang saya Kenal (terj. Surya Darma), Jakarta: Robbani Press, 1999, h. 99

${ }^{10}$ Muhammad al-Ghazali, Berdialog Dengan Al-Qur'an,..., h. 44
} 
halnya, maka apakah lagi jika hadits tersebut bertentangan dengan al-Qur'an? ${ }^{11}$

2. Sunnah Nabawiyah (hadits)

Sunnah nabawiyah adalah sumber kedua bagi Muhammad al-Ghazali. Dia sangat pandai dalam menukil hadits-hadits shahih dan hasan yang bisa dijadikan hujjah dan juga hadits-hadits dhaif yang bisa dipakai. Muhammad al-Ghazali sangat memperhatikan matan suatu hadits karena dia tidak ingin adanya hadits yang bertentangan dengan al-Qur'an dan akal sehat. Muhammad al-Ghazali berkesimpulan bahwa tidak ada satu haditspun yang bertentangan dengan hukum al-Qur'an, bahkan merupakan suatu hal yang mustahil jika ada hadits yang bertentangan dengan hukum-hukum alQur'an. Hal tersebut bisa dipastikan adanya kesalahan dalam segi penerapan persyaratan penerimaan hadits dari Nabi SAW.

Menurut Muhammad al-Ghazali sunnah penting dalam rangka memahami al-Qur'an, sunnah merupakan wujud penjelas dan praktis bagi al-Qur'an. Maka tidaklah mungkin penjelas berbeda dengan yang dijelaskan. ${ }^{12}$

Muhammad al-Ghazali tidak pernah mentakwil sebuah hadits yang mungkin butuh pentakwilan dan dia juga tidak mengenal metode al-Jam' bila terdapat beberapa hadits yang tampak bertentangan. Dia selalu menjustifikasi suatu hadits shahih atau dhaif. Hal ini dia lakukan demi kepentingan aplikasi hadits dalam kehidupan nyata. ${ }^{13}$

Karena hal ini pulalah salah satu yang menyebabkan dirinya banyak mendapatkan kritikan dan kecaman karena dinilai terlalu tergesa-gesa dalam mendhaifkan suatu hadits, padahal mungkin saja hadits itu masih bisa dikompromikan atau ditakwil.

Metodologi aplikasi hadits yang ditawarkan Muhammad al-Ghazali adalah teraplikasinya hadits nabawi ke dalam beberapa klasifikasi yaitu:

a. Hadits-hadits tasyri'yang berlaku mutlak diaplikasikan kapanpun dan dimanapun;

b. Hadits-hadits yang bukan tasyri' $i$ hadits seperti ini tidak mutlak diaplikasikan, namun menurut Muhammad al-Ghazali akan lebih baik jika hadits jenis ini diaplikasikan dalam dunia nyata;

c. Hadits-hadits yang berada di antara keduanya, jenis yang terakhir membutuhkan kepada penelitian yang mendalam tentang abash tidaknya pengamalan suatu hadits. ${ }^{14}$

Sedangkan indikasi keshahihan matan suatu hadits menurut Muhammad al-Ghazali adalah sejalan dengan al-Qur'an, sejalan dengan akal sehat, sejalan dengan matan hadits shahih lain, sejalan dengan fakta sejarah, sejalan dengan prinsip-prinsip Islam, tidak syadz, dan tiada "illah al-qadhihah. ${ }^{15}$

Indikasi keshahihan yang ditetapkan Muhammad al-Ghazali terlihat jelas sesuai dengan metode dan prinsip-prinsip dirinya seperti yang sering dia kemukakan dalam buku-buku dan ceramahnya. Muhammad alGhazali sangat menentang hadits-hadits yang maknanya berlawanan dengan al-Qur'an dan prinsip-prinsip Islam karena menurutnya menggunakan hadits tersebut hanya akan

${ }^{11}$ Muhammad al-Ghazali, As-Sunnah an-Nabawiyah Baina Ahl al-Fiqh Wa Ahl Al-Hadits, Beirut: Dar alSyuruq, 1989, h. 237

${ }_{12}$ Muhammad al-Ghazali, As-Sunnah an-Nabawiyah Baina Ahl al-Fiqh Wa Ahl Al-Hadits,..., h. 14

${ }^{13}$ Irsyadul Ibad, "Studi Tentang Pemikiran Muhammad Al-Ghazali Dalam Memahami Hadits Nabi" dalam Antologi Kajian Islam, Seri 9, IAIN Sunan Ampel Press, 2005, h. 15

${ }^{14}$ Muhammad al-Ghazali, As-Sunnah an-Nabawiyah Baina Ahl al-Fiqh Wa Ahl Al-Hadits,..., h. 14-15

${ }^{15}$ Irsyadul Ibad, "Studi Tentang Pemikiran Muhammad Al-Ghazali Dalam Memahami Hadits Nabi”,..., h. 15 
mendatangkan kerugian dan kerusakan dalam diri umat Islam.

Adapun dari segi pemahaman, Muhammad al-Ghazali tampaknya dalam menilai dan memahami suatu hadits terlebih dahulu membandingkannya dengan alQur'an. Sehingga hadits-hadits yang bertentangan langsung atau tidak langsung dengan al-Qur'an, walaupun dari segi periwayatan hadits itu dinilai shahih, tetap ditolaknya dan dinyatakan sebagai suatu hadits yang tidak shahih. Bahkan dia mengkritik orang-orang yang hanya menyibukkan diri dengan hadits dan kurang memperhatikan al-Qur'an.

Muhammad al-Ghazali menyatakan bahwa tidak ada hadits yang berlawanan dengan al-Qur'an, kalaupun pada suatu saat tampak adanya pertentangan, itu semata-mata disebabkan pemahamannya yang salah, bukan disebabkan keshahihan hadits itu sendiri. ${ }^{16}$

\section{Mashlahah mursalah}

Muhammad al-Ghazali menjadikan mashlahah mursalah sebagai sumber fiqh, namun dalam hal ini Muhammad al-Ghazali menetapkan persyaratan yaitu tidak boleh bertentangan dengan nash shahih yang tegas. Muhammad al-Ghazali menyatakan fiqh yang benar adalah dengan mengetahui mashlahat yang tidak ada nashnya, dalam seluruh bidang ini umat boleh melakukan ijtihad tanpa batas namun dalam konteks kemashlahatan. ${ }^{17}$

Walaupun dalam permasalahan yang tidak ada ketentuan nash yang secara tegas menjelaskannya, diperbolehkan berijtihad dan menggunakan mashlahah mursalah untuk menyelesaikannya. Namun Muhammad alGhazali mensyaratkan hal itu mesti sesuai dengan ketentuan umum dalam al-Qur'an, tidak boleh bertentangan dengan al-Qur'an.

4. Menghormati madzhab tanpa harus bersikap fanatik

Muhammad al-Ghazali menghormati seluruh madzhab fiqh yang memiliki pengikut maupun tidak tanpa harus bersikap fanatik terhadapnya atau salah satu darinya. Muhammad al-Ghazali hormat kepada dua aliran yang ada dalam pustaka fiqh yaitu aliran atsar dan aliran rasional. Muhammad alGhazali menganggap bahwa aliran atsar tidak menyepelekan pendapat ataupun fungsi akal dalam memahami qiyas terhadapnya, sebagaimana aliran rasional juga tidak terlepas begitu saja dari atsar dan sunnah. ${ }^{18}$

Terkadang Muhammad al-Ghazali cenderung ke aliran rasional dalam ijtihadijtihadnya berdasarkan keumuman dan lahiriah ungkapan al-Qur'an. Namun terkadang juga Muhammad al-Ghazali mengkritik aliran rasional, bila dia menemukan ada hal yang tidak tepat dalam ijtihadnya. Sebab rasionalis terkadang melewatkan begitu saja hadits-hadits sehat yang sebenarnya perlu dijadikan rujukan. Kadang mereka berijtihad namun tidak memiliki landasan pemikiran dan mashlahat.

Muhammad al-Ghazali mengkritik orang-orang yang berusaha menghilangkan khilafiyah lalu berusaha mengumpulkan manusia pada satu pendapat. Perbedaan pendapat itu sendiri telah ada sejak zaman Rasulullah masih hidup dan perbedaan itu merupakan rahmat di dalam Islam. Di lain segi Muhammad al-Ghazali juga menolak orang-orang yang terlalu memperbesarbesarkan urusan khilafiyah, sebab hal itu

${ }^{16}$ Muhammad al-Ghazali, Menjawab 40 Soal Islam Abad 20 (terj. M. Thohir dan Abu Laila), Bandung: Mizan, 1993, h. 131-136

17 Yusuf Al-Qardhawi, Syaikh Muhammad Al-Ghazali Yang saya Kenal,..,,h. 244

${ }^{18}$ Yusuf Al-Qardhawi, Syaikh Muhammad Al-Ghazali Yang saya Kenal,...,h. 244 
hanya akan membawa perpecahan umat dan kemunduran dalam dunia Islam. ${ }^{19}$

5. Fiqh yang berkhidmat kepada dakwah Menurut Muhammad al-Ghazali fiqh seharusnya berkhidmat kepada dakwah Islam, jangan sampai fatwa-fatwa parsial justru membuat orang non muslim semakin menjauh dari Islam atau keinginan dari orang muslim yang berdosa dan ingin bertaubat menjadi padam.

Menjadi keharusan bagi seorang ahli fiqh modern untuk mengkaji warisan keilmuan dari ulama-ulama terdahulu dalam berbagai zaman dengan satu pandangan baru di bawah cahaya Kitabullah, sunnah, maqasid as-syari'ah dan hukum-hukum Islam universal yang pasti. Dibolehkan mengambil atau meninggalkan pendapat para pemberi syarah, sebab nash itu ma'shum sedangkan pendapat pemberi syarah tidaklah ma'shum. ${ }^{20}$

Hal ini dilakukan oleh Muhammad alGhazali karena dia ingin orang-orang tertarik kepada Islam bukan malah membuat mereka semakin jauh dari agama Islam karena adanya suatu pendapat yang dalam Islam sendiri tidak diklaim sebagai pendapat yang benar.

Inilah rahasia di balik panasnya pergumulan Muhammad al-Ghazali dengan orang-orang yang memisahkan fiqh dari dakwah, mereka tidak memikirkan terhadap diri para objek dakwah yang berada di luar wilayah Islam, akibat dan pandangan dan pendapat yang mereka lahirkan.

\section{Pandangan Muhammad al-Ghazali tentang kesaksian wanita dalam perkara pidana}

Sebelum abad ke 6 Masehi status wanita sama seperti barang yang boleh diperjualbelikan. Mereka tidak dihormati dan dihargai sebagai seorang manusia, tidak mendapatkan hak yang sewajarnya sesuai dengan tugas dan tanggung jawab yang dilaksanakan. Kedatangan Islam mengubah fenomena ini, wanita tidak lagi diletakkan di tempat kedua sebagai pengikut laki-laki. Tetapi mereka mendapatkan hak dan status sewajarnya sesuai dengan fitrah penciptaannya. $^{21}$

Sesuatu yang amat berharga yang diberikan Islam kepada wanita adalah persamaan kedudukan dan kemanusiaannya dengan kaum laki-laki. Dengan datangnya Islam wanita diangkat harkat dan martabatnya sesuai dengan posisinya dan kodratnya sebagi wanita.

Sejalan dengan hal itu, Muhammad alGhazali menyatakan bahwa kesaksian seorang wanita sebagaimana yang diketahui dianggap setengah dari kesaksian seorang laki-laki. Alasannya karena wanita sering lupa, bingung atau kurang dapat memastikan mana yang benar dalam suatu urusan. Manakala ada seorang wanita lain yang mendampinginya, maka kedua-duanya dapat saling membantu dalam menjelaskan tentang sesuatu secara sempurna. $^{22}$

Muhammad al-Ghazali pernah melakukan penelitian dan mendapati wanita yang sedang dalam masa menstruasi hampirhampir menyerupai orang yang sedang sakit. Ditengah-tengah masa haid yang dialami seorang wanita setiap bulannya, kecuali jika terjadi kehamilan, wanita mengalami berbagai beban dan kesusahan pada fisiknya seperti mengalami rasa sakit pada bagian bawah dada dan perut, emosi menjadi labil, mengalami

\footnotetext{
${ }^{19}$ Yusuf Al-Qardhawi, Syaikh Muhammad Al-Ghazali Yang saya Kenal,...,h. 254

${ }^{20}$ Muhammad al-Ghazali, Berdialog Dengan Al-Qur'an,..., h. 80-81

${ }^{21}$ Andek Masnah Andek kelawa, Kepemimpinan Wanita Dalam Islam, Malaysia: UKM Malaysia, 2001, h. 13

${ }^{22}$ Muhammad al-Ghazali, As-Sunnah an-Nabawiyah Baina Ahl al-Fiqh Wa Ahl Al-Hadits,..., h. 58
} 
migran menjelang datangnya haid, kekurangan darah, dan lainnya. ${ }^{23}$

Prof. Kershy Shikavsky mengadakan percobaan psikologis pada wanita yang sedang haid, dia menyimpulkan bahwa wanita mengalami kepedihan pada kumpulan syarafnya, perasaan menjadi tumpul, perasaannya tertekan pada saat melakukan pekerjaan yang biasa dilakukan sebelumnya. Dicontohkan bila dia seorang sekretaris, dia sering mengalami kekeliruan pada saat mengetik serta lamban dalam mengerjakannya dan ia sering salah dalam menyusun kalimat. Bila dia seorang pengacara, pemaparan argumentasinya sering kurang rasional, bila dia seorang hakim akan berpengaruh pula dalam mengambil suatu keputusan. ${ }^{24}$

Muhammad al-Ghazali menyatakan bahwa faktor tersebutlah barangkali merupakan rahasia yang terkandung dalam suarat al-Baqarah ayat 282. Menurutnya seharusnya dalam urusan tersebut, harusnya berhenti hanya sampai di sini, akan tetapi sayangnya telah timbul penyimpangan dalam pemikiran muslim yang mutlak menjauhkan wanita dari kesempatan memberikan kesaksiannya dalam berbagai bidang peradilan yang amat penting yakni dalam qishas dan perkara pidana serta bidang lainnya yang bersangkutan dengan nyawa dan kehormatan manusia. ${ }^{25}$

Muhammad al-Ghazali mengatakan apa artinya menolak kesaksian wanita apabila ada pencurian atau pelanggaran terhadap jiwa dan anggota tubuh seseorang yang terjadi di depan mata kepala mereka sendiri.
Lebih lanjut Muhammad al-Ghazali menyatakan, "saya sekali-kali tidak ingin melemahkan agama saya di hadapan hukumhukum internasional dengan suatu sikap yang tidak berlandaskan nash-nash yang kuat. Apabila jumlah kaum muslimin di seluruh dunia mencapai lebih dari satu milyar manusia, pantaskan kita melemparkan kehormatan diri lima ratus juta wanita muslim hanya demi mengikuti pandangan seseorang? Kenapa kita tidak berpegang pada al-Qur'an yang telah menetapkan jumlah orang yang dapat diterima kesaksiannya, baik laki-laki maupun perempuan." 26

Muhammad al-Ghazali secara tegas menyatakan pendapatnya tentang kesaksian wanita dalam perkara pidana yaitu:

"Demi menyelamatkan diri sendiri dan juga banyak orang dari keadaan yang tidak wajar ini, maka sebaiknya kita hanya berpegang pada al-Qur'an yang tegas dan jelas dan sunnah an-nabawiyah yang benarbenar dikenal oleh para ahli. Sesungguhnya saya menyatakan dengan tegas diterimanya kesaksian wanita dalam semua urusan sesuai dengan batasan jumlahnya yang telah ditetapkan dalam agama kita. Memang merupakan hak bagi setiap muslim untuk meninggalkan segala sesuatu yang berada di luar ketentuan keduanya dan untuk itu dia tidak boleh dituduh dan dicurigai." 27

Muhammad al-Ghazali melontarkan pernyataan bahwa adakah termasuk kemashlahatan umum menolak kesaksian wanita dalam urusan yang sering terjadi di depan mata kepala mereka sendiri? Apakah

${ }^{23}$ Muhammad al-Ghazali, Dilema Wanita Di Era Modern (terj. Heri Purnomo), Jakarta: Mustaqim, 2003, h. 181

\footnotetext{
${ }^{24}$ M. Ali Hasan, Masail Fiqhiyah Al-Haditsah, Jakarta: Rajawali Pers, 2002, h. 196

${ }^{25}$ Muhammad al-Ghazali, As-Sunnah an-Nabawiyah Baina Ahl al-Fiqh Wa Ahl Al-Hadits,..., h. 58

${ }^{26}$ Muhammad al-Ghazali, As-Sunnah an-Nabawiyah Baina Ahl al-Fiqh Wa Ahl Al-Hadits,..., h. 59

${ }^{27}$ Muhammad al-Ghazali, As-Sunnah an-Nabawiyah Baina Ahl al-Fiqh Wa Ahl Al-Hadits,..., h. 60
} 
termasuk mashlahah fiqh dan sunnah untuk mengutamakan pendapat suatu madzhab yang lebih banyak merugikan Islam dari pada menguntungkannya.

Muhammad al-Ghazali sangat heran terhadap sikap para fuqaha yang melarang wanita mengemukakan kesaksiannya dalam perkara pidana. Padahal di dalam al-Qur'an tidak ada satu ayatpun yang melarang wanita mengemukakan kesaksiannya dalam perkara pidana.

Kalaupun ada hadits yang melarang wanita bersaksi dalam urusan thalaq dan hudud sebagaimana yang dikemukakan oleh beberapa fuqaha, hadits itu bukanlah hadits shahih. Bahkan kalau memang Rasulullah Rasulullah melarang wanita mengemukakan kesaksian dalam hal thalaq dan hudud, kenapa justru Imam Hanafi memperbolehkan kesaksian wanita dalam semua masalah perdata yang mencakup thalaq? Kenapa wanita tidak dilarang dalam kedua urusan tersebut sesuai dengan lafadz hadits?

Inilah salah satu faktor yang menyebabkan Muhammad al-Ghazali secara tegas menyatakan bahwa wanita berhak mengemukakan kesaksiaanya dalam semua masalah, termasuk perkara pidana sesuai dengan ketentuan jumlah saksi sebagaimana tercantum dalam al-Qur'an.

Pendapat Muhammad al-Ghazali ini juga dikuatkan oleh pendapat Ibnu Qayyim, dia menyatakan bahwa seorang wanita jika dia dapat dipercaya dapat diterima sebagai saksi. Jika wanita tersebut sempurna ingatannya tentang apa yang dilihatnya, adil dan juga cenderung relegius, maka hukum ditetapkan atas dasar kesaksiannya saja. ${ }^{28}$

\section{E. Analisis pemikiran Muhammad al- Ghazali tentang kesaksian wanita dalam perkara pidana}

Kalau dilihat secara lebih kritis pandanga jumhur ulama dan Muhammad alGhazali tentang kesaksian wanita dalam perkara pidana, maka didapati perbedaan yang sangat mencolok.

Jumhur ulama tidak memperbolehkan wanita mengemukakan kesaksiannya dalam perkara pidana. Hal ini dikarenakan para fuqaha menafsirkan ayat mengenai saksi dalam perkara pidana adalah saksi laki-laki. Mereka menilai wanita tidak bisa mengemukakan kesaksiannya dalam perkara pidana karena sifat wanita yang ragu-ragu dan pelupa sebagaimana yang digambarkan dalam surat al-Baqarah ayat 282.

Sedangkan Muhammad al-Ghazali berpendapat bahwa kesaksian wanita dalam perkara pidana dibolehkan asalkan sesuai dengan batasan jumlah yang telah ditentukan dalam al-Qur'an. Muhammad al-Ghazali menyatakan bahwa tidak ada satu ayatpun yang menyatakan saksi itu harus laki-laki dan juga tidak ada satu ayatpun di dalam al-Qur'an yang melarang wanita mengemukakan kesaksiannya dalam perkara pidana.

Pemikiran Muhammad al-Ghazali terhadap Islam dibentuk dari pemahamannya yang mendalam terhadap al-Qur'an dan hadits-hadits yang shahih, kedua hal inilah yang menjadi sumber utama bagi pemikirannya.

Muhammad al-Ghazali menilai bahwa konteks surat al-Baqarah ayat 282 yang mengharuskan adanya dua saksi wanita dalam memberikan kesaksian, hal ini semata-mata untuk memudahkan wanita mengingat suatu

\footnotetext{
${ }^{28}$ Ibnu Qayyim al-Jauziyyah, I'lamu Al-Muawaqqiin, h. 71 dikutip dari Anshoruddin, Hukum Pembuktian Menurut Hukum Acara Islam dan hukum Positif, Yogyakarta: Pustaka Pelajar, h. 133
} 
peristiwa. Muhammad al-Ghazali dalam mengemukakan pendapatnya tersebut mengaitkan denga hasil penelitian yang dilakukannya bahwa pada masa haid kondisi fisik wanita tidak stabil seperti sering lupa, cepat emosi, badan lemah dan lain sebagainya.

Hal ini menurut Muhammad al-Ghazali merupakan rahasia di balik apa yang tercantum dalam surat al-Baqarah ayat 282 . Seharusnya masalah ini berhenti sampai di sini, dan wanita perlu ada pendamping saksi lain untuk membantunya. Tetapi yang mengherankan Muhammad al-Ghazali kenapa jumhur ulama justru memperluas masalah ini dengan tidak diterimanya kesaksian wanita dalam perkara pidana.

Muhammad al-Ghazali berpendapat, pandangan yang melarang wanita mengemukakan kesaksiannya dalam perkara pidana bukannya mendatangkan kemashlahatan akan tetapi justru menimbulkan kerugian pada umat Islam sendiri. Pada kondisi dan tempat-tempat yang khusus wanita, bila terjadi peristiwa pidana di depan mereka sendiri, apakah logis ditolak kesaksian wanita dan dibiarkan pelaku kejahatan bebas berkeliaran dengan alasan tidak ada saksi laki-laki. Hal ini justru menimbulkan kerugian dan membiarkan kejahatan terus terjadi. Menurutnya tidak pantas bagi umat Islam menolak kesaksian wanita dalam perkara pidana hanya karena mengikuti suatu pandangan. Nampaknya Muhammad al-Ghazali menilai pendapat tersebut tidak sesuai dengan kondisi pada masa sekarang ini.

Namun walau bagaimanapun, Muhammad al-Ghazali harus diakui sebagai salah seorang cendekiawan muslim dewasa ini yang kritis dalam memahami hadits Nabi, namun justru sikap kritisnya ini telah mengundang kontroversial di antara para cendekiawan muslim dewasa ini.

Sebagian golongan menyatakan bahwa Muhammad al-Ghazali tidak mengikuti metode muhaddits dalam kegiatan seleksi mutu hadits, sehingga mengakibatkan sebagian hadits yang shahih menurut para muhaddits justru dianggap dhaif oleh Muhammad al-Ghazali.

Pada dasarnya pandangan Muhammad al-Ghazali terhadap pembagian hadits dari segi kualitas dan kuantitasnya tidak jauh berbeda dengan apa yang telah ditetapkan oleh para ahli hadits. Bahkan pada penetapan syarat-syarat keshahihan sebuah hadits, Muhammad al-Ghazali mengutip sejumlah persyaratan yang telah ditetapkan para muhaddits.

Muhammad al-Ghazali mengisyaratkan bahwa sesungguhnya dia bisa menerima periwayatan hadits ahad selama hadits tersebut memenuhi syarat-syarat keshahihan suatu hadits. Baik shahih dari segi sanadnya maupun matannya. Dalam hal ini tentu saja Muhammad al-Ghazali berbeda dengan sejumlah ulama dan pemikir lainnya yang menolak hadits ahad, dengan alasan bahwa status hadits ini dari segi periwayatannya hanya bertingkat zhanny al-wurud dan dari segi kehujahannya merupakan zhanny aldalalah. Hal ini dianggap meragukan sebagai sesuatu yang berasal dari Rasul. ${ }^{29}$

Di antara hadits-hadits yang digugat oleh Muhammad al-Ghazali adalah haditshadits yang menurut pandangannya bertentangan dengan al-Qur'an dan akal sehat. Meskipun hadits itu dikategorikan sebagai hadits shahih dan diriwayatkan serta telah

${ }^{29}$ Badri Khaeruman, Otentisitas Hadis; Studi Kritis Atas kajian Hadis Kontemporer, (2004), Bandung: PT Remaja Rosdakarya, h. 291 
dishahihkan oleh para muhaddits tetap ditolaknya.

Muhammad al-Ghazali sendiri mengakui persyaratan keshahihan hadits yang ditetapkan oleh para muhaddits, namun perbedaan terjadi dalam penerapannya. Muhammad al-Ghazali dalam memahami hadits memadukan model pemahaman hadits versi fuqaha dan muhaddits. Hal ini bisa diketahui bagaimana Muhammad al-Ghazali tidak terlalu memperhatikan sanad hadits tetapi dia lebih menitikberatkan pada matan hadits.

Sepertinya Muhammad al-Ghazali dalam mengemukakan pendapatnya juga dipengaruhi oleh kondisi sosial dan kultural pada masa dia hidup yang jauh berbeda dengan masa jumhur ulama. Muhammad alGhazali dalam mengemukakan pendapatnya juga dipengaruhi oleh kondisi politik pada saat dia hidup. Dimana dunia internasional menerima kesaksian wanita dalam berbagai permasalahan dan tekanan dari orang-orang non muslim yang menyudutkan Islam juga mempengaruhi pemikiran Muhammad alGhazali.

Apa yang ditulis dan dilakukan Muhammad al-Ghazali pada masa hidupnya sebagian memang menimbulkan kontroversial. Hal ini disebabkan oleh cara pandang dan metode yang dia gunakan. Namun tidak berarti Muhammad al-Ghazali seorang yang anti terhadap sunnah dan keluar dari jamah sebagaimana yang dituduhkan oleh sebagian orang. Akan tetapi apa yang telah dilakukan oleh Muhammad al-Ghazali tersebut merupakan niat yang tulus untuk menjauhkan ajaran Islam dari berbagai penyelewengan dan penyimpangan serta berusaha menjaga ajaran Islam dari tudingan para non muslim serta berusaha menghasilkan hukum yang relevan dengan perkembangan dan kebutuhan umat Islam pada masa sekarang ini.

\section{F. Penutup}

Muhammad al-Ghazali membolehkan kesaksian wanita dalam perkara pidana karena menurutnya tidak ada satu ayatpun di dalam al-Qur'an yang melarang wanita menjadi saksi dalam perkara pidana. Walaupun ada hadits, hadits tersebut bukanlah hadits yang kuat dan dirawikan dari jalur yang lemah.

Metode dan sumber-sumber utama pemikiran Muhammad al-Ghazali adalah alQur'anul karim, sunnah nabawiyah, mashlahah mursalah, menghormati madzhab tanpa harus fanatik dan fiqh yang berkhidmat kepada dakwah.

Indikasi keshahihan matan suatu hadits menurut Muhammad al-Ghazali adalah sejalan dengan al-Qur'an, sejalan dengan akal sehat, sejalan dengan matan hadits shahih lain, sejalan dengan fakta sejarah, sejalan dengan prinsip-prinsip Islam, tidak syadz, dan tiada 'illah al-qadihah.

Metodelogi aplikasi hadits yang ditawarkan Muhammad al-Ghazali adalah teraplikasinya hadits ke dalam beberapa klasifikasi yang meliputi hadits-hadits tasyri'i, hadits-hadits yang bukan tasyri'i dan hadits-hadits yang berada di antara keduanya.

\section{DAFTAR PUSTAKA}

Abdullah al-Aqil, Mereka Yang Telah Pergi (terj. Khozim Abu Faqih), (2003), Jakarta: al-I'tishom Cahaya Umat

Andek Masnah Andek kelawa, Kepemimpinan Wanita Dalam Islam, (2001), Malaysia: UKM Malaysia

Anshoruddin, Hukum Pembuktian Menurut Hukum Acara Islam dan hukum Positif, (2003) Yogyakarta: Pustaka Pelajar 
Badri Khaeruman, Otentisitas Hadis; Studi Kritis Atas kajian Hadis Kontemporer, (2004), Bandung: PT Remaja Rosdakarya

Ibnu Rusyd, Bidayatul Mujtahid (terj. Imam Ghazali Said), (1990) Jilid 3, Semarang: CV. Asy-Syifa

Irsyadul Ibad, "Studi Tentang Pemikiran Muhammad Al-Ghazali Dalam Memahami Hadits Nabi" dalam Antologi Kajian Islam, (2005) Seri 9, IAIN Sunan Ampel Press

Muhammad al-Ghazali, As-Sunnah anNabawiyah Baina Ahl al-Fiqh Wa Ahl Al-Hadits, (1989), Beirut: Dar al-Syuruq
Muhammad al-Ghazali, Berdialog Dengan Al-Qur'an (terj. Masykur Hakim), (1999), Bandung: Mizan

Muhammad al-Ghazali, Dilema Wanita Di Era Modern (terj. Heri Purnomo), (2003), Jakarta: Mustaqim

Muhammad al-Ghazali, Menjawab 40 Soal Islam Abad 20 (terj. M. Thohir dan Abu Laila), (1993), Bandung: Mizan

Muhammad Salam Madkur, Peradilan Dalam Islam (terj. Imron AM), (1993), Surabaya: PT. Bina Ilmu

Yusuf Al-Qardhawi, Syaikh Muhammad AlGhazali Yang saya Kenal (terj. Surya Darma), (1999), Jakarta: Robbani Press. 